\title{
Comparison of Learning Outcomes Between Discovery Learning with Inquiry Learning Reviewed of Student Learning Independence At Vocational High School
}

\author{
Febriani Lukitasari ${ }^{1, a *}$, Luthfiyah Nurlaela ${ }^{1, b}$, Rita Ismawati ${ }^{1,}$ \& Tri Rijanto ${ }^{4, d}$ \\ 1Department of Technology and Vocational Education, Postgraduate of State University of Surabaya, Surabaya, \\ 60213, Indonesia \\ a febrianilukitasari16070895005@mhs.unesa.ac.id, bluthfiyahnurlaela@unesa.ac.id, c ritaismawati@unesa.ac.id, \\ d tririjanto@unesa.ac.id \\ *Corresponding Author: febrianilukitasari16070895005@mhs.unesa.ac.id | Phone : +6285815712830
}

Received: 25 July 2020

Revised: 6 August 2020

Accepted: 11 September 2020

\begin{abstract}
The provision of education provides a positive value for the development of the quality of Human Resources (HR), because global challenges and competition between nations in various aspects of life are increasingly competitive. This study aims to find the effect of learning models find the effect of discovery learning learning models with inquiry learning learning models to increase student learning outcomes; find the effect of student learning independence on student learning outcomes; and find interactions between discovery learning, inquiry learning and student learning independence models on student learning outcomes.This type of research is a quasi-experimental study, which is to examine student learning outcomes in food knowledge subjects using discovery learning and inquiry learning models. The research design used in this study is factorial design. Data collection techniques were carried out by observation and tests. Instrument of student learning outcomes. This study concludes that: (1) there is a significant difference in the effect of discovery learning models compared to inquiry learning models on improving student learning outcomes; (2) there is a significantly higher difference in high learning independence compared to students with low learning independence on student learning outcomes, and (3) there is an interaction between discovery learning, inquiry learning and student learning independence towards student learning outcomes. Based on the above conclusions as a whole shows there are differences in the application of learning models, the level of independence and interaction between the use of learning models, and the level of independence of student learning outcomes.
\end{abstract}

Keywords: Discovery Learning; Inquiry Learning; Learning Independence; Learning Outcomes;

\section{Introduction}

The provision of education provides a positive value for the development of the quality of Human Resources (HR), because global challenges and competition between nations in various aspects of life are increasingly competitive. Therefore the birth of superior human resources and the realization of optimal intellectual gifted development of children who can compete in national and international or global scope must be accelerated (Hawadi, 2006).

The education system in Indonesia is experiencing continuous development at the level of education, starting from elementary schools to universities. One of them is the Vocational High School (SMK) which is one of the places of education to be able to develop the abilities possessed by individuals both in terms of cognitive, affective and psychomotor through the learning process conducted at school. It is expected to be able to produce young people who are intelligent, creative, nimble and responsible. Piaget explained, adolescence is a period of development in cognitive aspects that have reached the level of formal operations, so that student activity is the result of logical thinking (Santrock, 2007).

Education is a shared responsibility, be it the community or the government. One of the efforts made by the government to improve education in Indonesia is to make the 2013 Education Curriculum an improvement of the 2006 Curriculum or Education Unit Level Curriculum (KTSP). The development of K13 requires students to learn more independently, be disciplined in managing time, and carry out more focused and intensive learning activities so that the objectives of implementing K13 can be achieved properly. K13 expects students to be able to be independent and know what has been learned, what is being learned, and what must be learned. The learning process is complex and many factors influence it. 
The teacher has a position as an activist role in the process of student self optimization to achieve ideal quality. As an activator of the teaching and learning process it means that the teacher is not the only source of learning, but is able to plan or create other learning resources in order to create a conducive learning environment. Teachers can use appropriate learning methods, create a pleasant learning atmosphere, involve students to play an active role during the learning process. The teacher is an important figure who can improve student learning outcomes.

Independence is important because part of the personal attitude that is needed by every individual. According to Utari Sumarmo $(2006$, p.5) students who have learning independence students tend to learn better, are able to monitor, evaluate, and manage their learning effectively, save time efficiently, will be able to direct and control themselves in thinking and acting, and don't feel dependent on others emotionally. Students are able to analyze complex problems, are able to work individually or in collaboration with groups, and dare to express ideas because they have the independence of student learning. Independence of learning really needs to be owned by every student because according to the theory of constructionvism, in the learning process at school, teachers cannot give students knowledge just like that. Learners must build their own knowledge the research aims: 1) find differences in student learning outcomes using discovery learning learning models with students using inquiry learning; 2) find differences in students' learning independence towards increasing student learning outcomes using discovery learning learning models with students using inquiry learning; 3) find interactions between discovery learning models, inquiry learning and student learning independence of student learning outcomes.

\section{Methods}

The study was conducted from March 2015 to January 2016. Seed viability and vigor analysis were conducted at the laboratory of Seed Science and Technology, Department of Agronomy and Horticulture, Bogor Agricultural University. Limau Lime (Citrus amblycarpa (Hassk.)) seed was obtained from Plantation in Bogor, Indonesia.

This type of research is a quasi-experimental study, which aims to test student learning outcomes in food knowledge subjects using discovery learning and inquiry learning models. In this research, the independent variable is the use of learning models, where one class is taught using discovery learning models and one class is taught using inquiry learning models.

Factorial research design shows that prior to the treatment which is the occurrence of the relationship resulted in an impact, namely in the form of acquisition of learning outcomes, conducted first the initial test to both classes. The test is used to determine the students' initial abilities before being treated. The initial test score becomes an indicator of learning achievement by calculating the difference with the final test results. Thus, each research subject will be known through learning outcomes obtained before and after being treated. Factorial design as shown in Figure 1.

$$
\begin{array}{cccccc}
\text { E } & \mathrm{O}_{1} & \mathrm{X}_{1} & \mathrm{Y}_{1} & \mathrm{O}_{3} \\
& & \mathrm{Y}_{2} & \mathrm{O}_{4} & & \\
\mathrm{~K} & & \mathrm{O}_{2} & \overline{\mathrm{X}_{2}} & \mathrm{Y}_{3} & \mathrm{O}_{5} \\
& & \mathrm{Y}_{4} & \mathrm{O}_{6} & &
\end{array}
$$

Figure 1. Factorial Design

Information:

E: Experiment class

$\mathrm{K}$ : Control class

O1,2: Pre-test

O3,4,5,6: Post-test

X1: Experimental class treatment (discovery learning)

$\mathrm{X} 2$ : Control class treatment (inquiry learning)

Y1,3: High level of independence

Y2,4: Low level of independence

The sample used in this study were two (2) classes, namely Class X JB 1 and X JB 2, where one class as an experimental class and one class as a control class. Both of these groups have the same background characteristics that are from the background of Catering. Data collection techniques are tools used to filter information that can describe the research variables. The data collection techniques used are as follows: (1) In 
the initial stages, it is carried out directly at school by observing the learning process, learning models used, student and student learning outcomes and learning tools used; (2) Data on cognitive domain learning outcomes in the experimental class and the control class were obtained through the results of the pretest and posttest; (3) Data on affective domain learning outcomes is obtained from observing attitudes when the learning process takes place; and (4) Student activity data obtained by observing or evaluating the teacher during the learning process. The research instrument is a tool or facility used by researchers in collecting data so that the data collection work is easier and the results are good, in the sense of being more accurate, complete, and systematic so that it is more easily processed

Tabel 1. Learning Media of Discovery Learning

\begin{tabular}{clcc}
\hline No & \multicolumn{1}{c}{ Device } & Average & Category \\
\hline 1 & Syllabus & 4,62 & Very Valid \\
2 & Lesson plan (RPP) & 4,69 & Very Valid \\
3 & Student worksheet (LKS) & 4,60 & Very Valid \\
\hline
\end{tabular}

Based on the Table 1 it is known that the results of syllabus validation by five validators obtained an average score of 4.62 with very valid criteria. The results of the RPP validation by five validators obtained an average score of 4.69 with very valid criteria. The results of LKS validation by five validators obtained an average score of 4.60 with very valid criteria.

The results of the validation of the learning kit by experts in the form of inquiry learning learning tools can be summarized in Table 2 as follows.

Tabel 2. Learning Media of Inquiry Learning

\begin{tabular}{llcc}
\hline No & \multicolumn{1}{c}{ Device } & Average & Category \\
\hline 1 & Syllabus & 4,53 & Valid \\
2 & Lesson plan (RPP) & 4,31 & Valid \\
3 & Student worksheet (LKS) & 4,27 & Valid \\
\hline
\end{tabular}

Based on the Table 2 it is known that the results of syllabus validation by five validators obtained an average score of 4.53 with valid criteria. The results of RPP validation by two validators obtained an average score of 4.31 with valid criteria. The results of LKS validation by two validators obtained an average score of 4.27 with valid criteria.

Analysis of student learning outcomes in this study includes the assessment of cognitive domain learning outcomes, affective domain learning outcomes and psychomotor domain learning outcomes. Cognitive domain learning outcomes analysis was obtained from evaluation scores (post-test). This needs to be done with the aim to determine the mastery of student learning both individually and completeness classically.

Analysis of differences in student competencies with the application of discovery learning learning models and the application of inquiry learning learning models in terms of student learning independence in food knowledge subjects includes 3 learning outcomes, namely: (1) cognitive domain learning outcomes, (2) affective domain learning outcomes, and (3) psychomotor learning outcomes and the experimental class were conducted using an independent sample t-test. T-test is used to determine differences in competence between two different circumstances. In testing the t-test using SPSS 24 software. Before calculating the t-test it is necessary to pay attention to the prerequisite tests which consist of: (1) normality test, and (2) homogeneity test. (Sugiyono, 2013; 140).

\section{Results and Discussions}

The normality test data for the discovery learning model of high independence and low independence, the learning outcomes of students in the class learned with the discovery learning model of high independence and low independence are said to be normally distributed if the specification score obtained by normality testing $>0.05$.

Table 3. Normality Test Learning Model Discovery Learning High Independence and Low Independence Tests of Normality

\begin{tabular}{lccc}
\hline & Kolmogorov-Smirnova & & \\
\cline { 2 - 4 } & Statistic & df & Sig. \\
\hline DiscoveryLearning_TR & 0,106 & 32 & $0,200^{*}$ \\
\hline${ }^{*}$. This is a lower bound of the true significance. \\
a. Lilliefors Significance Correction
\end{tabular}

Based on testing the normality of student realm learning outcomes Table 3 shows that in classes taught by discovery learning models in high and low independence students have a significance level $>0.05$ which is 0.200 . Thus the class taught by the discovery learning model of high independence and low independence in normal distribution. 
The normality test data of the Inquiry learning model learning high independence and low independence, student learning outcomes in classes learned with the Inquiry learning model high independence and low independence are said to be normally distributed if the specification score obtained by normality testing $>0.05$.

Table 4. Normality Test Learning Model Inquiry Inquiry High Independence and Low Independence Tests of Normality

\begin{tabular}{lccc}
\hline & & & \\
\cline { 2 - 4 } & Kolmogorov-Smirnova & df & Sig. \\
\hline InquiryLearning_TR & 0,115 & 32 & $0,200^{*}$ \\
\hline *. This is a lower bound of the true significance. & & & \\
a. Lilliefors Significance Correction & & & \\
\end{tabular}

Based on testing the normality of student learning outcomes Table 4 shows that in classes taught with inquiry learning models on high student independence and low independence has a significance level> 0.05 which is 0.200 . Thus the class taught by the inquiry learning model on high student independence and low independence is normally distributed.

Table 5. Homogeneity Test Results Student Learning Outcomes Learning Models Discovery Learning and Inquiry Learning

\begin{tabular}{|c|c|c|c|c|}
\hline & Levene Statistic & df1 & $\mathrm{df} 2$ & Sig. \\
\hline Learning outcomes & 0,000 & 1 & 62 & 0,987 \\
\hline
\end{tabular}

Based on testing criteria, if the significance level $<0.05$ then the sample variance is not the same, conversely if the significance level $>0.05$ then the sample variant is the same or homogeneous. According to the homogeneity test results above have a variance score of 0.987 with a significance level of $>0.05$, it can be concluded that testing the learning outcomes of students learning models Discovery Learning and Inquiry Learning has the same or homogeneous variance.

Tests of Between-Subjects Effects

Table 6. Hypothesis Testing Student Learning Outcomes

Dependent Variable: Hasil_Belajar

\begin{tabular}{ll|l|l|l|l}
\hline Source & Type III Sum of Squares & df & Mean Square & F & Sig. \\
\hline Corrected Model & $5008.922 \mathrm{a}$ & 3 & 1669.641 & 18.788 & .000 \\
\hline Intercept & 399898.141 & 1 & 399898.141 & 4500.032 & .000 \\
\hline Learning model & 395.016 & 1 & 395.016 & 4.445 & .039 \\
\hline Learning Independence & 968.766 & 1 & 968.766 & 10.901 & .002 \\
\hline Learning_ Model * Independence & 3645.141 & 1 & 3645.141 & 41.019 & .000 \\
\hline Error & 5331.938 & 60 & 88.866 & & \\
\hline Total & 410239.000 & 64 & & & \\
\hline Corrected Total & 10340.859 & 63 & & & \\
\hline
\end{tabular}

a. $\mathrm{R}$ Squared $=.484$ (Adjusted $\mathrm{R}$ Squared $=.459)$

The first hypothesis testing in this study discusses the differences in student learning outcomes for students who are taught using discovery learning models with students who are taught using discovery learning models. Based on the two path variance data in Table 6. above, the F value of 4.445 is obtained with a significance value of $0.039<0.05$. It can be concluded, that there are significant differences in the learning outcomes of students taught by using the discovery learning model that is 8.45 , compared to the learning outcomes of students who are taught using the inquiry learning model of 7.89.

The second hypothesis testing in this study discusses the differences in student learning outcomes for students who have high learning independence, significantly higher than the learning outcomes of students who have low learning independence Based on the two path variance data in Table 6 above obtained an $\mathrm{F}$ value of 10.901 with a value of significance of $0.002<0.05$. it can be concluded, that there are differences in student learning outcomes for students who have high learning independence, significantly higher than the learning outcomes of students who have low learning independence.

The third hypothesis testing in this study discusses the interaction between discovery learning, inquiry learning and student learning independence models. Based on the two path variance data in Table 6 above, the $\mathrm{F}$ value of 41.019 is obtained with a significance value of $0.000<0.05$. It can be concluded, that there is a significant interaction between discovery learning model, inquiry learning and student learning independence towards. The following graphs the interaction of student learning outcomes on the influence of discovery learning models, inquiry learning and student learning independence can be seen in Figure 2 as follows. 


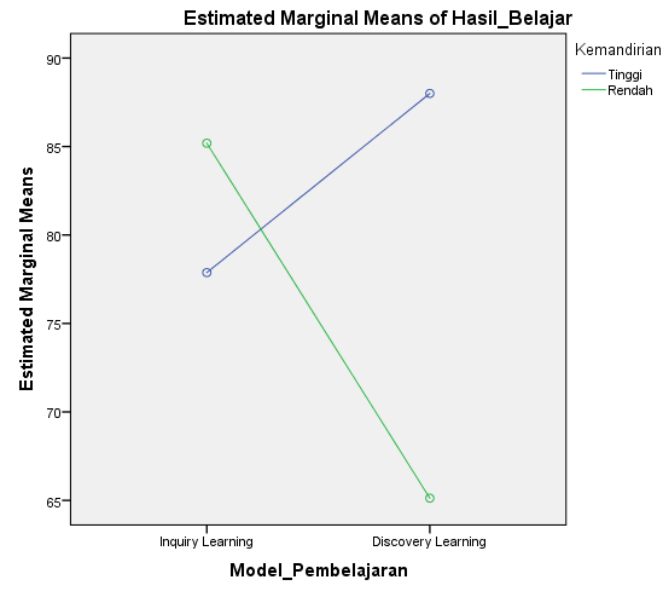

Figure 2. Interaction Graph between (Discovery Learning and Inquiry Learning) and Learning Independence on Student Learning Outcomes

Based on Figure 2, the graph of interaction between learning models and learning independence of student learning outcomes shows that there is an interaction because there are intersecting lines. High learning independence in discovery learning model has higher learning independence, while in inquiry learning model has lower learning independence. Low learning independence in discovery learning model has higher learning independence, while in inquiry learning model has lower learning independence.

\section{Conclusion}

There is a significant difference between the learning outcomes of students who are taught using discovery learning models with an average value of 84.5 higher than students who are taught using inquiry learning models with an average value of 78.9; there is a significant difference in the learning independence of students who are taught using discovery learning models compared to students who are taught using inquiry learning models, students who are taught with discovery learning (83) levels of independence are higher than those taught with inquiry learning (80); there is an interaction between discovery learning model, inquiry learning and student learning independence of student learning outcomes with a significant number of 0,000 .

\section{References}

Arikunto, S. (2011). Prosedur Penelitian Suatu Pendekatan Pratik Edisi Revisi VI. Jakarta: PT Rineka Cipta.

Clemons, T.L. (2008). Underachieving gifted students: A social cognitive model. The National Research Centre on The Gifted and talented. Universutay of Virginia.

Dimyati dan Mudjiono. (2009). Belajar dan Pembelajaran. Jakarta: PT Rineka Cipta.

Ellianawati dan Wahyuni. (2010). Pemanfaatan Model Self Regulated Learning (SRL) Sebagai Upaya Peningkatan Kemampuan Belajar Mandiri Pada Mata Kuliah Optik. Diunduh dari http//www.journal.unnes.ac.id. Diakses pada tanggal 3 Juni 2019. pp:223-239.

Emmy, B, dan Sjef. (2012). Effects of Increased Self-Regulated Learning Opportunities on Student Teachers' Motivation and Use of Metacognitive Skills. Australian Journal of Teacher Education, Vol. 37, No 6. Diunduh dari http// search.proquest.com. Diakses pada tanggal 3 Juni 2019. pp:102-117.

Febrianela, R. (2013). Self Regulated Learning (SRL) Dengan Prestasi Akademik Siswa Akselerasi. Jurnal Ilmiah Psikologi Terapan Vol. 1, No 1. Universitas Muhammadiyah Malang. Diunduh dari http//www.ejournal.umm.ac.id. Diakses pada tangga 3 Juni 2019. pp:202-213.

Hasan, I. (2009). Analisis Data Penelitian Dengan Statistik. Jakarta: PT Bumi Aksara.

Hasbulloh. (2010). Dasar-dasar Ilmu Pendidikan. Jakarta : PT Raja Grafindo Persada.

Lilik, D., dan Wagimin. (2010). Tingkat Penguasaan Self Regulated Learning Skills (SRLS) Ditinjau Dari Segi Prestasi Belajar dan Lama Studi Mahasiswa FKIP UNS. Diunduh dari www.journalpsikologi.com. Diakses pada tanggal 3 Juni 2019. pp:63-73.

Purwanto.P. (2000). Hubungan Self-regulated learning dengan Prestasi Belajar. Yogyakarta: Fakultas Psikologi UGM.

Rusman. (2012). Model-Model Pembelajaran. Jakarta: Grafindo 
Sudjana, N. (2012). Penilain Hasil Proses Belajar Mengajar. Bandung: PT Remaja Rosdakarya. Sugiyono. (2010). Metode Penelitian Kuantitatif, Kualitatif, Dan RED. Bandung: Alfabeta.

Supranto. J. (2009). Statistik:Teori dan Aplikasi. Jilid 1. Edisi 7. Jakarta: Erlangga.

Syah, M. (2010). Psikologi Pendidikan dengan Pendidikan Baru. Bandung: PT Remaja Rosdakarya.

Usman, H., dan Akbar, P.,S. (2006). Pengantar Statistika. Jakarta: Bumi Aksara.

Wiyono, B.,B. 2008. Metodologi Penelitian. Malang : Fakultas Ilmu Pendidikan Universitas Negeri Malang. 